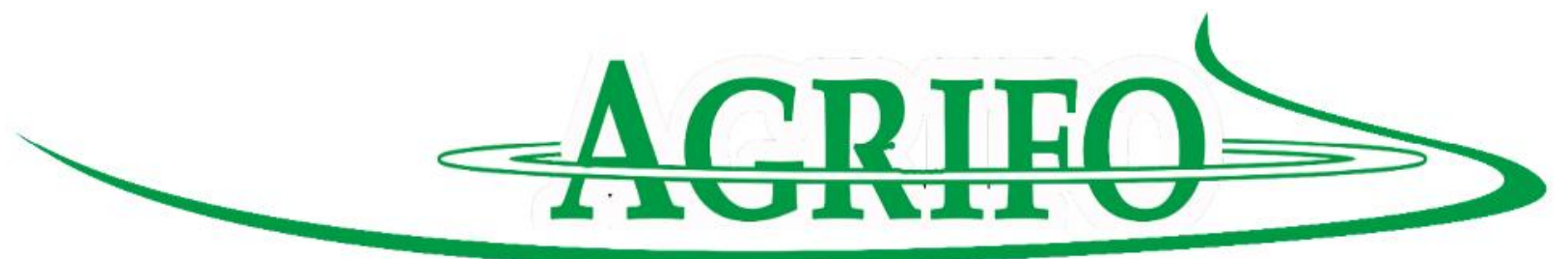

\title{
UPAYA PENGEMBANGAN USAHA EKONOMI KREATIF KERAJINAN BORDIR ACEH DI KABUPATEN ACEH UTARA
}

\author{
Hafni Zahara \\ Staff Pengajar Program Studi Agribisnis Universitas Malikussaleh \\ Email: hafni.zahara@unimal.ac.id
}

\begin{abstract}
ABSTRAK
Penelitian ini berjuan untuk mengetahui Upaya pengembangan usaha ekonomi kreatif kerajinan bordir Aceh dalam bidang produksi, pemasaran, dan kemampuan beradaptasi dengan pasar yang dilakukan oleh pengusaha kerajinan bordir di Kabupaten Aceh Utara. Penelitian ini menggunakan metode survey, dan penentuan lokasi dilakukan secara sengaja (purposive) di Kabupaten Aceh Utara. Pengumpulan data dilakukan melalui observasi, wawancara dan studi literatur. Metode penelitian yang digunakan dalam penlitian ini adalah deskriptif kualitatif. Hasil penelitian menunjukkan bahwa (1) Dalam pengembangan produk, pengusaha ekonomi kreatif kerajinan bordir Aceh selalu melakukan inovasi dalam menciptkan produk baru dan melakukan pengontrolan terhadap kerapian bordir juga kualitas barang. (2) Selanjutnya dalam bidang promosi dan pemasaran, pengusaha melakukan kegiatan promosi barang secara online melalui media sosial seperti instagram dan facebook. Promosi juga dilakukan dengan cara mengikuti bazar, pelatihan dan pameran yang dilaksanakan oleh berbagai instansi baik pemrintah maupun swasta. (3) pada pengembangan kemampuan dalam beradaptasi dengan pasar, pengusaha mampu menciptakan produk yang sesuai dengan keinginan konsumen. Pengusaha mampu menciptakan produk yang kreatif dan inovatif juga bersifat kekinian, misalnya tas bola atau round bag, alas meja motif bordir Aceh, dan kotak hantaran yang bermotif bordir Aceh.
\end{abstract}

Kata Kunci; upaya pengembangan usaha, kerajinan bordir Aceh, ekonomi kreatif

\section{PENDAHULUAN}

Tujuan dari pengembangan ekonomi kreatif adalah untuk dapat meningkatkan pendapatan masyarakat dan melestarikan kebudayaan lokal suatu daerah. Selain itu, pengembangan ekonomi kreatif juga diperlukan untuk mengatasi permasalahan ekonomi dan dapat dijadikan solusi untuk mensejahterakan masyarakat, karena dalam sistem ekonomi kreatif memberikan nilai tambah baik kepada usahanya sendiri ataupun kepada sumberdaya manusianya atau masyarakat.

Pengembangan ekonomi kreatif juga dapat meningkatkan pendapatan asli daerah karena dapat menyerap banyak tenaga kerja pada 
proses produksinya, selain untuk mengatasi permasalahan ekonomi. Pada beberapa jenis produk, hasil 22 produksi industri kecil di bidang pangan, sandang, kulit, kimia, dan bidang kerajinan mempunyai prospektif untuk ekspor (Hubeis 2010). Oleh karena itu, ekonomi kreatif perlu dikembangkan karena dapat menciptakan iklim bisnis yang positif, dapat memperkuat citra dan identitas bangsa Indonesia, mendukung pemanfaatan sumberdaya yang terbarukan, merupakan pusat penciptaan inovasi dan pembentukan kreativitas, dan memiliki dampak sosial yang positif (Depdag 2008).

\section{Upaya pengembangan}

merupakan hal yang mutlak dan harus dilakukan oleh pemilik usaha agar usahanya dapat berjalan lancar dan tidak mengalami kebangkrutan. Upaya yang harus dilakukan oleh pemilik usaha harus tepat dengan kondisi dan kebutuhan perusahaannya juga kondisi dan kebutuhan pasar. Kurangnya upaya pengembangan atau kurang efektifnya upaya pengembangan dapat mengakibatkan kemunduran usaha, oleh karena itu upaya pengembangan haruslah tepat dan efektif dalam pelaksanaannya.

Usaha kerajinan bordir Aceh di Kabupaten Aceh Utara cukup berkembang, hal ini ditunjukkan oleh bertambahnya jumlah unit usaha saat ini dan permintaan produk yang selalu meningkat baik di tingkat lokal, nasional maupun internasional.untuk itu perlu adanya pengembangan usaha pada bidang produksi, sehingga pengusaha mempunyai kreatifitas yang tinggi dan mampu menciptakan produk yang sesuai dengan keinginan pasar tanpa menghilangkan ciri khas daerah yaitu motif bordir khas Aceh. Disamping itu pengembangan usaha pada bidang promosi dan pemasaran juga tidak kalah penting, untuk dapat memperkenalkan produknya ke masyarakat luas. Dan untuk dapat membantu mengembangkan usaha, mejalin kemitraan dengan usaha lain juga sangat diperlukan.

Penelitian ini bertujuan untuk mengetahui Upaya pengembangan usaha ekonomi kreatif kerajinan bordir Aceh dalam bidang produksi, promosi dan pemasaran, dan kemampuan beradaptasi dengan pasar 
yang dilakukan oleh pengusaha kerajinan bordir di Kabupaten Aceh Utara.

\section{METODE PENELITIAN}

Penelitian ini dilaksanakan di Kabupaten Aceh Utara. Alasan pengambilan lokasi ini berdasarkan pertimbangan bahwa Kabupaten Aceh Utara merupakan sentra unit usaha kerajinan bordir Aceh yang ada di Provinsi Aceh.

Populasi dalam penlitian ini adalah seluruh pengusaha ekonomi kreatif kerajinan bodir Aceh yang aktif melakukan kegiatan usahanya di Kabupaten Aceh Utara.

Ruang lingkup penelitian
hanya dibatasi pada Upaya pengembangan usaha ekonomi kreatif kerajinan bordir Aceh dalam bidang produksi, pemasaran, dan bidang kemitraan dengan usaha lain yang dilakukan oleh pengusaha kerajinan bordir di Kabupaten Aceh Utara. Objek penelitian ini adalah Pemilik Usaha Ekonomi Kreatif Krajinan Bordir Aceh di Kabupaten Aceh Utara.
Pada penelitian ini, jenis data yang dikumpulkan adalah data primer dan data sekunder. Data primer dikumpulkan melalui pengamatan langsung dan wawancara terstruktur dengan pmilik usaha kerajinan bordir dipandu dengan daftar pertanyaan yang telah disiapkan terlebih dahulu.

Analisis data yang digunakan dalam penelitian ini adalah Analisis deskriptif kualitatif, digunakan untuk menggambarkan upaya pengembangan usaha ekonomi kreatif kerajinan bordir Aceh dalam bidang produksi, pemasaran, dan kemampuan beradaptasi dengan pasar yang dilakukan oleh pengusaha kerajinan bordir di Kabupaten Aceh Utara.

\section{HASIL DAN PEMBAHASAN}

\section{Kondisi Usaha Kerajinan Bordir}

Usaha kerajinan bordir Aceh merupakan salah satu usaha kerajinan bordir yang tumbuh sejak 20 tahun yang lalu. Usaha ini terus berkembang dengan baik hingga saat ini. Hal ini dikarenakan usaha ini merupakan usaha yang sudah dijalani 
oleh keluarga secara turun temurun. Usaha kerajinan bordir semakin berkembang pesat dengan pembinaan

oleh Dinas Perindustrian dan
Perdagangan juga kantor perwakilan

Bank Indonesia (BI) cabang

Lhokseumawe melalui program klaster di Desa Ulee Madon Kecamatan Muara Batu Kabupaten Aceh Utara.

\section{Terdapat 175 pengusaha} kerajinan bordir di Aceh Utara yang tersebar di lima Kecamatan yaitu Kecamatan Muara Batu, Dewantara, Sawang, Nisam, dan Lhok Sukon. Kecamatan Muara Batu merupakan kecamatan yang paling banyak pengusaha kerajinan bordir dibandingkan kecamatan yang lainnya. Skala usaha juga berbeda dari setiap kecamatan tersebut, ada yang skala usaha rumah tangga, usaha kecil, dan usaha besar. skala usaha besar lebih banyak terdapat di Kecamatan Muara Batu dan Lhok Sukon.

Secara umum tidak ada pendidikan khusus atau pelatihan yang diikuti oleh pengusaha ekonomi kreatif kerajinan bordir Aceh di Aceh
Utara, mereka memperoleh pengetahuan tentang teknis menjahit bordir dari ibu mereka yang sudah menekuni usaha tersebut secara turun temurun. Namun ketika pasca tsunami Aceh 2004 silam banyak donatur dan para NGO yang melaksanakan program pelatihan dan pendampingan pemulihan trauma pasca tsunami dengan cara mengisi waktu luang dengan berbagai kegiatan positif. Salah satunya program pelatihan kerajinan bordir.

Kerajinan bordir ini menggunakan motif khas Aceh yang merupakan warisan budaya yang sudah ada sejak zaman kerajaan Iskandar Muda di wilayah Aceh, yaitu motif khas Aceh yang natural dan penuh kreatifitas. Motif yang biasa digunakan adalah pintoe Aceh, pucok rebong, rencong, dan motif lainnya. Penggunaan motif tradisional ini biasanya dikombinasikan dengan motif yang sedang tren saat ini dan disesuaikan dengan produk yang diciptakan.

Produksi kerajinan bordir Aceh terus meningkat setiap tahunnya (Tabel 1), hal ini dikarenakan usaha 
kerajinan bordir Aceh terus berkembang semenjak dijadikannya Desa Ulee madon sebagai klaster kerajinan bordir Aceh. Pembinaan dan pelatihan juga terus dilakukan oleh dinas terkait, mengingat Provinsi Aceh sedang mengembangkan ekonomi kreatif guna mendukung industri pariwisata di Provinsi Aceh. Industri pariwisata akan berkembang

apabila didukung oleh pelaku ekonomi kreatif yang handal. Oleh karena itu, Aceh terus berupaya mengembangkan ekonomi kreatif, salah satunya dengan cara meningkatkan kapasitas pengrajin guna menumbuhkan daya kreasi para pelaku ekonomi kreatif agar mampu menghasilkan sebuah produk yang berkualitas.

Tabel 1. Jumlah produksi kerajinan bordir Aceh

\begin{tabular}{llrr}
\hline No & Jenis produk & \multicolumn{2}{c}{ Jumlah produksi (buah) } \\
\cline { 3 - 4 } & & \multicolumn{2}{c}{2011} \\
\hline 1 & Tas & 1.230 .000 & 1.580 .000 \\
2 & Dompet & 67.450 & 80.650 \\
3 & Peci & 167.000 & 245.000 \\
4 & Mukena & 235.000 & 525.200 \\
5 & Setelan baju & 248.281 & 356.291 \\
6 & Sajadah & 16.500 & 17.800 \\
& Total & 2.164 .231 & 2.804 .941 \\
\hline
\end{tabular}

Sumber: Dinas perindustrian dan perdagangan Aceh Utara (2013)

Produk yang biasa dibuat para pengusaha adalah berupa tas, dompet, kopiah haji/peci, pakaian, koper, dan lain sebagainya. Motif bordir khas Aceh yang digunakan berupa motif awan meu-arak, pucok reubong, pinto Aceh, rencong dan iku abo. Kombinasi warna dan motif yang digunakan sangat indah dan menarik, sehingga produk yang dihasilkan selalu laku dipasaran baik pasar lokal, nasional, dan internasional.

\section{Upaya Pengembangan Usaha Bidang Produksi}

Produksi yang baik dan unik sangat diperlukan dalam upaya pengembangan usaha kerajinan bordir sehingga usaha yang dikelola berkembang dengan baik, seperti yang dikemukakan oleh Ahyani R,dkk (2012) upaya pengembangan usaha dilakukan dengan menetapkan strategi pengembangan usaha dan 
melakukan inovasi dan variasi dalam pengembangan produk.

Proses pembuatan produk bordir 26

Aceh tergolong lama dan rumit. Prosesnya dimulai dengan pembuatan pola/desain, pemotongan kain, menggambar pola, membordir kain dengan mesin jahit biasa, lalu dilanjutkan dengan finishing yaitu penjahitan dan perakitan dengan mesin $y u k i$, dan produk siap untuk dipasarkan. Proses perakitan atau finishing dilakukan oleh tenaga kerja laki-laki, karena memerlukan tenaga yang kuat dan keahlian khusus, makanya bagian ini dikerjakan oleh tenaga kerja laki-laki. Sedangkan membuat pola, memotong kain, dan menjahit bordir dilakukan oleh tenaga kerja perempuan yang sudah terampil pada bidangnya. Alat yang digunakan dalam proses ini adalah mesin jahit biasa, mesin jahit yuki, gunting, jarum jahit, meja potong, penggaris, dan kapur warna. Sedangkan bahanbahannya adalah kain prada hujan, kain japandrill, kain beludru, dan benang.

Upaya pengembangan usaha bidang produksi dilakukan oleh pengusaha adalah untuk meningkatkan produksi baik secara kualitas dan kuantitas. Kualitas produk sangat ditentukan oleh bahan baku yang digunakan, tingkat kerapian bordir, kombinasi warna benang pada motif bordir Aceh, kualitas jahitan pada bagian akhir atau finishing tas dan pengontrolan oleh pengusaha untuk setiap unitnya. Untuk itu pengusaha selalu melakukan pengontrolan tahap akhir saat barang akan dikirimkan ke konsumen.

\section{Upaya Pengembangan Usaha Bidang Promosi dan Pemasaran}

Konsep pemasaran yang digunakan dalam memasarkan produk usaha kerajinan bordir Aceh merupakan konsep 4P tambah 1P yang dikenalkan oleh Basu Swasta (2010) yaitu sebuah falsafah bisnis yang menyatakan bahwa pemuasan kebutuhan konsumen merupakan syarat ekonomi dan sosial bagi kelangsungan hidup perusahaan. Konsep tersebut adalah: Product, Price, Placement, Promotion, dan People. 
Product merupakan hasil akhir dari suatu kegiatan usaha yang dilakukan oleh pengusaha bordir dengan menggunakan bahan baku kain prada, benang, karet sol, dan peralatan lainnya, yaitu berupa tas bordir, dompet, tempat tisu, pakaian, peci, dan lain sebagainya. Produk usaha kerajinan bordir Aceh sudah dikenal masyarakat luas, produk yang diciptakan sudah memenuhi standar kualitas terbaik, dengan menggunakan kreativitas dan inovasi sehingga tercipta produk yang sesuai dengan permintaan pasar yang kekinian.

Price yaitu Menentukan harga produk yang dipasarkan. Harga produk yang akan dijual tentunya harus bisa diterima dipasaran, artinya harga harus sesuai dengan kualitas barang yang akan dipasarkan. Setiap produk kerajinan bordir Aceh memiliki berbagai komponen biayanya sendiri, dari awal produksi hingga produk tersebut dipajang di display penjualan. Jika pembelian dilakukan dalam jumlah besar, maka akan diberikan potongan harga untuk setiap produknya.
Placement merupakan tempat atau saluran distribusi. Dalam hal ini didefinisikan sebagai tempat untuk memasarkan produk atau jasa yang ditawarkan. Lokasi klaster kerajinan bordir Aceh di Desa Ulee Madon berada di jalan Negara Medan-Banda Aceh, dimana lokasi ini sangat strategis dan sangat mudah dijangkau oleh konsumen karena berada ditepi jalan raya, ini penting supaya mudah diakses oleh konsumen.

Promotion Aspek penting lainnya adalah mengenai promosi dari produk. Bagaimana suatu produk akan dikenalkan ke pasar agar pelanggan tergerak untuk membelinya. Salah satu media promosi yang dilakukan oleh pengusaha kerajinan bordir Aceh adalah melalui brosur yang disebarkan ketika mengikuti pameran, juga promosi dilakukan melalui media internet dengan cara melakukan pemasaran secara on line, misalnya melalui instagram, facebook, dan lainnya.

People (orang/SDM), inti dari pemasaran yang semula berorientasi pada produk (producer), kemudian 
bergeser menjadi orientasi penjualan (seller), pemasaran (marketer), dan terakhir berorientasi pada pelayanan

\section{8}

sumber daya. Ini dilakukan pada penjualan langsung yang terjadi di sentra kerajinan bordir Aceh dan outlet souvenir Aceh, pelayanan yang memuaskan dilakukan oleh pemilik usaha salah satunya memberikan salam kepada pengunjung, dan menyuguhkan minuman air mineral dan permen kepada konsumen yang sedang berbelanja atau hanya sekedar melihat-lihat. Selain itu pelayanan antar barang juga biasa dilakukan oleh pengusaha bordir aceh kepada konsumen yang jauh

\section{Upaya Pengembangan Usaha Bidang Kemampuan Beradaptasi dengan Pasar}

Upaya pengembangan usaha bidang kemampuan beradaptasi dengan pasar, digeluti dengan serius oleh para pengusaha ekonomi kreatif kerajinan bordir Aceh. Dalam hal ini kemampuan pengusaha dalam membaca selera pasar sangat baik, mampu memahami apa yang dibutuhkan oleh konsumen sesuai dengan trend saat ini. Kemampuan tersebut dicirikan oleh jenis produk yang diciptakan pengusaha sangat bervariasi juga model, warna, dan motif-motif yang digunakan sangat beragam dan menaik.

Kuantitas dan kualitas produk berperan penting dalam menentukan produktivitas usaha. Peningkatan produktivitas usaha salah satunya dicirkan dari kemampuan pengusaha dalam menciptakan produk sesuai dengan keinginan konsumen. Untuk itu produsen perlu memfokuskan diri pada konsumen sehingga mampu menguasai pasar, (Alex 2008). Kemampuan menguasai pasar oleh pengusaha kerajinan bordir Aceh dapat dilihat pada keberagaman produk yang diciptakan. Pada awalnya kerajinan bordir hanya pada pakaian/baju dan tas, namun seiring perkembangan mode, maka produk yang dihasilkan juga semakin banyak antara lain dompet HP, tas lap top, travel bag, tempat tissue, peci, dan produk-produk lainnya. Model tas yang diproduksi juga semakin beragam disesuaikan dengan model tas yang terkenal saat ini, misalnya tas bola atau round bag yang sedang 
trend kekinian sekarang ini, juga produk kotak hantaran yang bermotif bordir Aceh.

Dukungan pameran juga sangat mendukung pengrajin untuk mampu beradaptasi dengan pasar. Dengan adanya pameran dan pengusaha mengikuti pameran tersebut maka pengusaha semakin mudah melihat dan mengetahui produk apa yang sedang diminati konsumen saat ini. Salah satu pameran yang dlaksanakan di Aceh adalah pameran Pekan Kebudayaan Aceh (PKA) yang dilaksanakan empat tahun sekali di Banda Aceh. PKA merupakan pameran terbesar dan termegah di Aceh yang diikuti oleh seluruh Dinas di Provinsi Aceh Tamu yang hadir juga tidak hanya dari Provinsi Aceh, tetapi dari Provinsi lain seperti Sumatera Utara bahkan dari Negara tetanga Malaysia dan Singapura. Tamu-tamu yang hadir sangat senang dengan produk kerajinan bordir Aceh yang unik dan menarik, dan mereka membelinya sebagai oleh-oleh buat keluarga dan kerabatnya disana.

\section{KESIMPULAN}

Berdasarkan hasil penelitian yang telah dikemukakan, maka dapat ditarik kesimpulan berupa:

1) Untuk meningkatkan upaya dalam pengembangan produk, pengusaha ekonomi kreatif kerajinan bordir Aceh melakukan inovasi dalam menciptkan produk baru dan melakukan pengontrolan terhadap kerapian bordir juga kualitas barang.

2) Pada bidang promosi dan pemasaran, pengusaha melakukan kegiatan promosi barang secara online melalui media sosial seperti instagram dan facebook. Promosi juga dilakukan dengan cara mengikuti bazar, pelatihan dan pameran yang dilaksanakan oleh berbagai instansi baik pemerintah maupun swasta.

3) Upaya pengembangan kemampuan dalam beradaptasi dengan pasar, pengusaha melakukan kegiatan menciptakan produk yang sesuai dengan keinginan konsumen. Pengusaha mampu menciptakan produk yang kreatif dan inovatif juga bersifat 
kekinian, misalnya tas bola atau round bag, alas meja motif bordir Aceh, dan kotak hantaran yang 30
Edication Journal (FFEJ)

volume 1 Tahun 2012.

Semarang: Universitas Negeri

Semarang.

Alex, Koutsoris. 2008. Innovating Towards Sustainable Agriculture: "A Greek case Study Department of Agricultural Economics and Rural Development, Agricultural University of Athens, Greece." The journal Agricultural Education and Extension Publication details, including instructions. For: http://www.informaworld.co m/smpp. [diunduh: 15 Desember 2013]

infomasi terkait pameran kerajinan kepada pengusaha, dan memfasilitasinya sehingga mereka dapat mengikuti pameran untuk meningkatkan pengetahuan dan pengalaman dalam bidang promosi dan pemasaran.

\section{DAFTAR PUSTAKA}

Ahyani R, Urip W, Wahyuningsih U. 2012. Upaya Pengembangan Usaha Kerajinan Bordir. Jurnal Fashion and Fashion
[DEPDAG] Departeman Perdagangan. 2008. Ekonomi Kreatif Indonesia 2025. Buku 1 Rencana Pengembangan Ekonomi Kreatif Indonesia 2009-2015. Jakarta: Depdag.

Hubeis AVH. 2010. Pemberdayaan Perempuan dari Masa ke Masa. Bogor: IPB Press

Toffler A. 1987. Kejutan dan Gelombang. Dra Sri 
Koefdiyantinah SB,

penerjemah. Jakarta:

Terjemahan dari Previews and

Premises.

Zahara Hafni. 2013. Kapasitas

Perempuan dalam

Pngembangan Ekonomi

Kreatif Kerajinan Bordir

Aceh. [Tesis]. Bogor. Institut

Pertanian Bogor. 